この場合も得さ学定める式は，賀界層内のエネルギ のつりあいの式であり，また運動量の变化の割合から せん断充力を計算したてととなっている。

数优例として，既知解のある二，三の場合について 解き，結果を比較した。

(1) 昭 28-10-11 倠酉工学連合会連合請演会和上び 昭 29-3-20

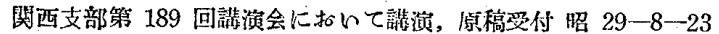
本諭交的論文集 101 皆に揭载。（2，（3）正員，大阪大学工学部。 (4) 学生員, 大阪大学工学部.

$534.015: 531.391 .1$

\section{採垂鎖の振動に関する一実験 (1)}

$$
\text { 入江 敏博 }{ }^{(2)} \text { ，小西一良(3) }
$$

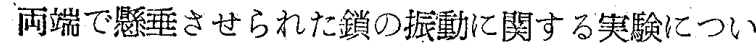
て報告する。鎖の一端を固定し，他端に可变速交流電 動機によって駆動せられるクランク機棈を通してかく 乱(ほぼ正弦かん数的强制変位) 范与气，共振現象苍利 用して各種のたわみの鎖の固有振動数を测定し，また 振動のモードを各種次数のものについて写真撮影し

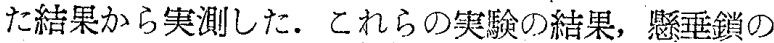
固有振動数がそのたわみの增大するに従って減少する てと，振動の次数に刘してはいかなるたわみのものも ほとんど淔線的に増加すること，扔よび鎖の場合の乇 ードは获のそれに比していささか変化するものである ことを明らふけした。

(1) 昭 28-11-16 東海:支部名古屋地方集演会に打的て䍀演，原稿受

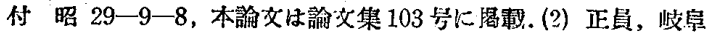
大学農学部. (3) 名古屋大学工学部.

\subsubsection{1}

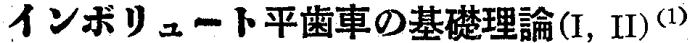

\section{荻、野修作 ${ }^{(2)}$}

第 エ報に扣いては通常の外接かみ合の場合の，第II 報に打いては通常の内接汃み合の場合の菌車論を展開 する.

まず成瀨敎授のいわゆる歯車の一般式を必要かつ十 分な形に述べ，ついでそれ它かみ合率 $n$ ，蒾数比 $\varepsilon$, かみ合圧力角 $\alpha$ を与えるとき，雨菌車の菌末の圧力角 $\theta_{1}, \theta_{2}$ の間の条件式とみなして具体化する.

ところで $n, \varepsilon$ を与えるとかみ合压力危 $\alpha$ は

外接加み合の場合は $0<\alpha<\sin ^{-1} 1 / \sqrt{ } 2 n$

内接汃み合の場合は $\sqrt{ } 2 n-1 / 2 n-\sin ^{-1} 1 / \sqrt{ } 2 n$ $\leqq(\varepsilon-1) \alpha-\varepsilon \tan ^{-1}\{(1-1 / \varepsilon) \tan \alpha\}$

なる条件をみたさねばならぬ。しの条件の下可逆蔽 車が可能なるための $\theta_{1}, \theta_{2}$ の間の条件式が $\left(\theta_{1}, \theta_{2}\right)$ を座標平面上の点として考察するここにより， $\alpha$ の值

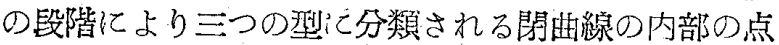
なるしとを示すことか知られる。そしてての結果に基 ずいて $n, \varepsilon, \alpha$ を与えるときの最大最小菌数間題か澥 明される。

更に $n, \varepsilon, \alpha$ を与えるとさすべての可能なる可逆菌

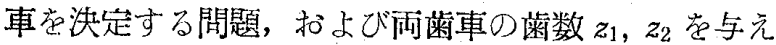

るときすべての可能なる可逆菌車を決定する問題が舠 汃れる。

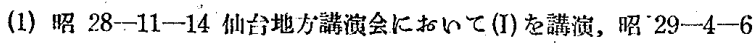

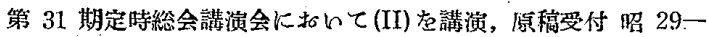

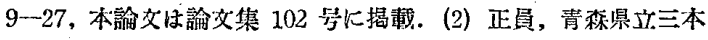
木高等学校.

\subsection{1,53.4:669.017-41}

金属薄板のショアかたさの測定について (1)

吉沢武 男(2)

薄板のかたさをショアかたさ試験烧で測定するてと は纩しくないにもか加わらず，いろいろ都合小点为 あって行われている。との論交は薄板のショアかたさ を測定する場合，下教のかたさの影響扣よび試料を幾 枚か重ね合わせたときの変化を明らかにするために行 った実験結果の郝告で，結局試料が薄い場合でも雷ね てかたさを測ること纯不都合であって，1枚でけで測 るがよく，乙の際受台または下謷のかたさがある限度 以上かないちのであればショアかたさの測定值は一定 となる。

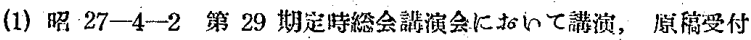

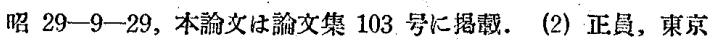
大学工学部.

$532.522: 665.5$

\section{薄刃管オリフィスによる油の流量測定(1)} 板谷松樹(2), 他 3 名 ${ }^{(3)}$

油の流量測定を目的として管径だよび開日比を種々 変えて管オリフィスの流量係数 $\alpha$ を禾統的に実測した 結果は, $\alpha$ は水, 空気の場合と異なり $m, D, R e$ 亿 よって変化する。等者らは実験值と最大 $2 \%$ 以内違 いで一致する実験式を作った。

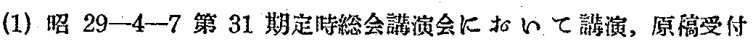

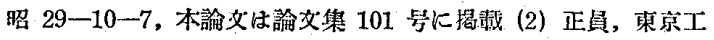
業大学. (3) 竹中缓夫, 正員, 東京工業大学. 宫沢鶴男, 正員, 石川島重工業会社. 久保 明, 正員, 石川帛重工業会社.

\subsection{4}

\section{一軸ねじポンプの実験(1)}

$$
\text { 竹中俊夫 }{ }^{(2)} \text {, 野田㕍太郎(3) }
$$

ねじのらせん状曲面を平面に閶開し，流れを二头元 曆流として取报うことによって谷の梁さとリード角の 最良值を求め, 一軸ねじポンプ設計の基礎式を作っ た。.

てれに基き試作した一軸ねじポンプについて兴先す きま，流体の粘度，ポンプの回転数などを種くに変化

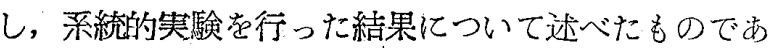
る。

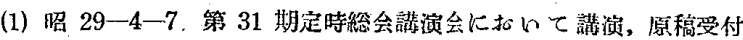

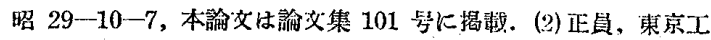
業大学.（3）准員，石川鼻重工策会社. 